\title{
Determinants of online clothing review helpfulness: the roles of review concreteness, variance and valence
}

DOI: $10.35530 / I T .072 .06 .1781$

YIBING SHAO

LILIN CAI

XIAOFEN JI

SONIA AKTER

\begin{abstract}
REZUMAT
Determinants of online clothing review helpfulness: the roles of review concreteness, variance and valence

Online reviews have emerged as an essential information source for online clothing purchasing behaviour. It is thus paramount for marketers to understand what makes online clothing review helpful to consumers. This research primarily aims to examine the relationship between review textual content factors and review helpfulness in the context of online clothing purchasing. Experiments on review concreteness (concrete or abstract), review variance (consistent or inconsistent) and review valence (positive or negative), between participants were conducted to explore the interaction effect. The findings suggest that online clothing review concreteness, variance and valence are significant factors affecting review helpfulness. Additionally, this study's findings show that abstract review, negatively review and inconsistent review has a stronger effect on online clothing review helpfulness than concrete review, positively review and consistent review. The findings will help customers to write better clothing reviews, help retailers to manage their websites intelligently and aid customers in their product purchasing decisions.
\end{abstract}

Keywords: online clothing review, review helpfulness, review concreteness, review variance, review valence

Determinanți ai utilității recenziei online a îmbrăcămintei: rolurile concreteții, variației și valenței recenziei

Recenziile online au apărut ca o sursă de informații esențială pentru comportamentul de cumpărare online a îmbrăcămintei. Prin urmare, este esențial pentru specialiștii în marketing să înțeleagă ceea ce face utilă recenzia online a îmbrăcămintei pentru consumatori. Această cercetare își propune în primul rând să analizeze relația dintre factorii de conținut textual al recenziilor și utilitatea recenziei în contextul achiziționării de îmbrăcăminte online. Au fost efectuate experimente privind concretețea recenziei (concretă sau abstractă), variația recenziei (consecventă sau inconsecventă) și valența recenziei (pozitivă sau negativă), între participanți, pentru a analiza influența interacțiunii. Rezultatele sugerează că, concretețea, variația și valența recenziei online a îmbrăcămintei sunt factori importanți care influențează utilitatea recenziei. În plus, concluziile acestui studiu arată că recenzia abstractă, recenzia negativă și recenzia inconsecventă au o influență mai puternică asupra utilității recenziei online a îmbrăcămintei decât recenzia concretă, recenzia pozitivă și recenzia consecventă. Rezultatele îi vor ajuta pe clienți să scrie mai bine recenzii despre îmbrăcăminte, pe comercianții cu amănuntul să-și gestioneze site-urile web în mod inteligent și pe clienți în deciziile lor de cumpărare a produselor.

Cuvinte-cheie: recenzie online a îmbrăcămintei, utilitatea recenziei, concretețea recenziei, variația recenziei, valența recenziei

\section{INTRODUCTION}

Advance online communication technologies, and massive distribution of internet connection have transformed the traditional face-to-face word-ofmouth (WOM) communication to electronic word-ofmouth (E-WOM) communication. E-WOM refers to any positive or negative statement made by potential, actual or former consumers about a product or service, which is made available to a multitude of people and institutions via the internet [1]. Consumers can use various internet-based platforms such as retailers' websites, brand community, independent websites, consumer blogs etc., to share experiences and opinions about a product or service [2]. Online reviews are a form of electronic word-of-mouth (E-WOM) and provide information based on the posted personal experience of previous buyers of a specific product working as free "sales assistants" to help other consumers identify the product that best matches their needs and preferences [3]. Online reviews are seen to be helpful for both potential customers and product manufacturers. To illustrate, on the customers' side, they can use online reviews to support their decision whether to purchase a particular product or not. On the other hand, for product manufacturers, they understand customers' current preferences from online reviews and utilize the knowledge in product development, marketing, and customer relationship management [4]. Indeed, a survey conducted by Nielsen among 28,000 Internet users from 56 countries reported that $70 \%$ of respondents considered online reviews a trustworthy source of information, ranking them as the second most trusted form of 
advertising among 19 different choices. As a result, marketing practitioners are interested in learning how to effectively stimulate and manage online reviews [5]. A significant number of studies examined online reviews from different perspectives, such as their effect on consumer expectations, customer satisfaction determinants, psychological influences, and firm responses.

But, ironically, too much online reviews also leads to information overload and consequently, inferior decision making [6]. Consumers are looking for online reviews that can assist them in their decision making. Whether an online review contributes to product evaluation and purchase decision, in other words, its utility or diagnosticity, is commonly measured by the review "helpfulness" [7]. Consumers are more receptive to obtain helpful online reviews with little searching effort; it is imperative that consumers may have access to helpful online reviews. The perceived helpfulness of the information obtained from online reviews positively affects consumers' attitudes for decision making [8]. Therefore, Businesses search for practices that facilitate the generation of helpful reviews on their e-commerce or review site in order to enhance their value to users. To investigate factors that make online reviews helpful for buyers are an essential research question.

Customers' preference seemed to have started changing gradually, in favour of shopping products online in regards to clothing products. Fashion clothing houses are no longer expecting profitable growth and expansion by purely focusing on the traditional marketing strategies only, instead, in a favourable market condition, the firms' marketing mix requires the integration of online marketing tools as well. Online reviews have emerged as an essential information source for online clothing purchasing behaviour. Online clothing reviews are abundant, complex bundles of information that reflect consumers' experiences and evaluation of products. We draw research attention towards this important market as online reviews highly influence it. Clothing products have an experience goods attribute (experience goods refer to products whose quality can be ascertained only after a purchase), it is difficult to obtain information and to compare the product attributes, because consumers usually need to see physically, smell, touch, or use them, and different consumers are likely to form heterogeneous opinions based on a single product attribute. Although there are several studies investigating consumer information adoption, e-WOM, online review helpfulness, few studies are discussing the helpfulness of online clothing reviews. Investigating the perceived helpfulness of online clothing reviews is not only beneficial to consumers but also to retailers. Furthermore, no studies have been conducted so far investigating the independent effect of online clothing review concreteness, online clothing review variance and online clothing review valence on the helpfulness of online clothing reviews. This study seeks to fill this gap. The findings are expected to provide a guideline for consumers on how to write a helpful review in response to clothing products and also provide insights for clothing retailers and fashion company on recommending helpful reviews to potential consumers.

The virtual environment forces consumers to evaluate online clothing reviews primarily based on their content. Content-related characteristics are found to be more influential than context-related characteristics for online clothing review helpfulness. This study aims to address an interesting but unanswered question: What is the influence of different review content related online clothing reviews helpfulness, with a specific focus on latent content variables on perceived review helpfulness? Does online clothing review concreteness, online clothing review variance and online clothing review valence influence the helpfulness of online clothing reviews?

The following research objectives are defined for this work:

- To examine the impact of review valence on perceived helpfulness of online clothing reviews;

- To examine the impact of review concreteness on perceived helpfulness of online clothing reviews;

- To examine the impact of review variance on perceived helpfulness of online clothing reviews.

The rest of the paper is organized as follows. We introduce the relevant conceptual framework and establish hypotheses in Section 1; Section 2 describes the research methodology (research design, pretest and data collection, manipulation check etc.) in detail followed by Section 3, which presents results and findings. Then Section 4 and 5 conclude with a discussion of the implications of our studies and suggestions for further research.

\section{LITERATURE REVIEW AND HYPOTHESES}

\section{Literature review}

Online review helpfulness. Online review helpfulness defines the perceived value of a review to its readers and measures consumer's evaluation of a review. It illustrates the degree to which a review contributes to a purchase decision by determining the level of its adoption by potential customers. In recent years, research on the helpfulness of online reviews has become a hot topic and focus. Academic researchers have advocated the benefits of helpful reviews and identified traits of a helpful product review. An increasing number of studies have explored factors that influence online review helpfulness. These factors include the content and context characteristics of the review. Content characteristics refer to the features that are derived from the review content, including review length, and review emotion. The context characteristics refer to the features, including reviewer expertise and reputation, review extremity, and reviewer disclosure [8]. Some scholars found that a review's extremity, review depth, and product type affect its perceived usefulness [9]. Generally speaking, consumers are influenced by both types of attributes 
when deciding which reviews to consider and which to reject.

Online review concreteness. Online review concreteness is a semantic feature representing what kinds of words are generally used in a message. Within the context of online clothing reviews, review concreteness can be seen as a type of textual content specificity ranging from objective facts (concrete) to abstract and emotional content based on subjective experience (abstract). From a communication standpoint, review concreteness is expected to be an important feature for online review perceived helpfulness. A number of studies have found the influence of textual concreteness on individuals' perception. Previous studies measured review concreteness using the text length (word count) and, thus, the concept of concreteness was oversimplified; however, the present research used the original concept of concreteness by manipulating the textual content of online reviews to be concrete or abstract. As such, it is argued that online review concreteness is a useful concept that allows us to understand how shopping experience could be represented through semantic features in online clothing reviews and, consequently, how it could impact on consumers who are seeking information for decision making.

Online review valence. Online review valence also referred to as review ratings, which is the positive and negative orientation of information that represents the reviewer's general opinion towards a product or service. The measurement of review valence can be obtained by average value of review score or can be identified directly by review text evaluation. Online review valence is a critical factor that affects product sales [10]. A number of studies have examined the influence of review valence on consumers' producer service evaluations. Researchers hold different views on the effect of positive and negative reviews on consumer behaviour. In comparing positive online reviews, some researchers found that negative online reviews have a considerable effect on consumer responses because they can find information about specific problems other consumers may encounter when using the products. Customers tend to pay more attention to negative than positive reviews. Scholars argued that people regard negative reviews as more helpfully, and they respond more saliently to them than to positive ones [11]. This relationship is also moderated by brand strength, with positive online reviews exerting a greater influence on products with weak brands [12].

Online review variance. Review variance refers to the extent to which message content is consistent with or similar to others regarding the same product or service. Cheung et al. [13] measured review variance through the degree of consensus and similarity with other reviews of the same product. Consensus with the aggregated rating on websites also indicates the variance of review rating. Information in online review in high different with those provided by other reviewers is perceived as helpful. People likely believe information when the content is inconsistent across different sites and sources. Studies found that online review variance positively affects the perceived helpfulness.

\section{Research hypotheses}

Based on the above discussions, the following hypotheses are proposed for further examination.

H1. Online clothing review concreteness is significance influences to review helpfulness.

$\mathrm{H} 1 \mathrm{a}$. The effect of review concreteness on online clothing review helpfulness is differential; compared with concrete review; abstract review has a stronger effect on online clothing review helpfulness.

$\mathrm{H} 2$. Online clothing review valence is significantly influencing to review helpfulness.

$\mathrm{H} 2 \mathrm{a}$. The effect of review valence on online clothing review helpfulness is differential; compared with positive review; negatively review has a stronger effect on online clothing review helpfulness.

H3. Online clothing review variance is significantly influences to review helpfulness;

$\mathrm{H} 3 \mathrm{a}$. The effect of review variance on online clothing review helpfulness is differential; compared with consistent review; inconsistent review has a stronger effect on online clothing review helpfulness.

\section{METHODS}

\section{Research design}

Experimentation is appropriate as it allows for the manipulation of one or more independent variables and measurement of their effects on dependent variables. To control for potential confounding factors, such as unwelcome environmental interruptions, we opted to conduct the experiment in a controlled laboratory setting. Experiments on review concreteness (concrete or abstract), review variance (consistent or inconsistent) and review valence (positive or negative), between participants were conducted to explore the interaction effect. The dependent variable was online clothing review helpfulness. We chose a fictitious brand name for the clothing in this study because we did not want the brand to influence the review evaluation. Review contents were adapted to actual reviews of mogujie.com, the famous website for online clothing purchase in China. Participants first read an online shopping scenario involving the purchase of clothing for them. They were instructed to imagine the situation as if it really occurred to them. All measurement instruments in this study were adopted and adapted from prior studies.

A pre-test was conducted to assess whether the research protocol was feasible, and if the measures of the study variables were effective. In total, 20 students from a university in China were invited to join the pilot test on a voluntary basis. To ensure validity, respondents were asked whether they thought the statements measured the corresponding variables after finishing the survey. Feedback regarding the selection of garment was recorded. Modifications 
were made to improve scenarios and the revised questionnaire was used in the main survey. We recruited Chinese university students to participate in the experiment because they constitute an important segment (a major portion) of online clothing shoppers in China. A total of 275 students from a large public university in China participated in the experiment; these students have experience of purchasing clothing products online. A few cases were removed as a result of incomplete or untrustworthy responses, resulting in 269 cases for analysis. The participants were randomly assigned to eight treatment groups. Participants' average age was 20.92 years, and $59.1 \%$ of the subjects were female.

The collected data were analysed using the statistical package for the social sciences software. A two-step approach was applied for data analysis. The first step aimed to ensure content validity and reliability. To ensure content validity, the measurement items were adopted from prior studies. Cronbach's alpha was computed from the data to ensure guarantee internal consistency and reliability. The second-step sought to address the research objectives and test the hypotheses. A three-way analysis of variance was applied to explore the main and interaction effects of online clothing review concreteness, online clothing review variance and online clothing review valence on online review helpfulness.

\section{Manipulation check}

We assessed the success of the manipulation of the independent variables with a few questions. We verified online clothing review concreteness manipulation by asking the subjects to rate the following measurement item on a five-point Likert scale: "The review I read describes the details of the products." The results showed that the manipulation was well achieved. The independent t-test for review concreteness suggested that the manipulated online clothing reviews as concrete or abstract were perceived as intended $\left(\mathrm{M}_{\text {concrete }}=4.45, \mathrm{M}_{\text {abstract }}=1.13\right.$, $t=10.75, p<0.01)$. By asking the subjects about whether the review was consistent with other reviews; the results showed that the review consistent manipulation was well achieved $\left(\mathrm{M}_{\text {consistent }}=\right.$ 4.32, $\left.\mathrm{M}_{\text {inconsistent }}=1.25, \mathrm{t}=11.530, \mathrm{p}<0.01\right)$. By asking the subjects about whether the review was positive; the results showed that the review variance manipulation was well achieved $\left(\mathrm{M}_{\text {positive }}=4.48\right.$, $\left.M_{\text {negative }}=1.49, t=9.230, p<0.01\right)$. These suggested a successful manipulation. Perceived online clothing review helpfulness, the dependent variable, was measured using three measurement items adapted from Huang et al. [10]: (i) "This review improves my ability to make a decision on whether or not to buy this product"; (ii) "This review provides me with insights into whether or not I would like this product"; and (iii) "The review contains useful information about this product". All of the items are reflective indicators and were measured on a five-point Likert scale, where, $5=$ strongly agree, 4 = agree, $3=$ neutral, $2=$ disagree, 1 = strongly disagree (Cronbach's alpha $=0.74$ ).

\section{RESULTS}

We ran ANOVA analyses using online clothing review helpfulness as the dependent variable. As shown in table 1 , the main effects of online clothing review concreteness $(F=13.804, p=0.005)$; online clothing review valence $(F=55.511, p=0.000)$; and online clothing review variance $(F=57.846, p=0.000)$ were statistically significant. Results indicate that review content attributes including review concreteness, valence, and variance are significant factors affecting online clothing review helpfulness. Hence, $\mathrm{H} 1, \mathrm{H} 2$,

Table 1

\begin{tabular}{|l|c|c|c|c|c|}
\hline \multicolumn{5}{|c|}{ TEST OF EFFECTS ON ONLINE CLOTHING REVIEW HELPFULNESS } \\
\hline \multicolumn{1}{|c|}{ Source of variation } & $\begin{array}{c}\text { Type III sum } \\
\text { of squares }\end{array}$ & Df & $\begin{array}{c}\text { Mean } \\
\text { square }\end{array}$ & F-ratio & Sig. \\
\hline Corrected model & 266.029 & 7 & 3.244 & 72.53 & $0.000^{* * *}$ \\
\hline Intercept & 1478.034 & 1 & 1478.034 & 1152.82 & $0.000^{* * *}$ \\
\hline Online clothing review concreteness & 19.511 & 1 & 4.878 & 13.804 & $0.005^{* *}$ \\
\hline Online clothing review valence & 28.263 & 1 & 7.066 & 55.511 & $0.000^{* * *}$ \\
\hline Online clothing review variance & 40.235 & 1 & 3.402 & 57.846 & $0.000^{* * *}$ \\
\hline $\begin{array}{l}\text { online clothing review concreteness * online clothing } \\
\text { review valence }\end{array}$ & 51.028 & 1 & 1.895 & 42.653 & $0.001^{* * *}$ \\
\hline $\begin{array}{l}\text { Online clothing review concreteness *online clothing } \\
\text { review variance }\end{array}$ & 2.432 & 1 & 2.917 & 2.478 & 0.114 \\
\hline Online clothing review valence *review variance & 40.833 & 1 & 1.123 & 12.275 & $0.006^{* *}$ \\
\hline $\begin{array}{l}\text { Online clothing review concreteness *nline clothing } \\
\text { review valence *online clothing review variance }\end{array}$ & 2.203 & 1 & 1.282 & 1.876 & 0.643 \\
\hline Error & 303.858 & 252 & - & - & - \\
\hline Total & 5642 & 260 & - & - & - \\
\hline Corrected total & 569.888 & 259 & - & - & - \\
\hline
\end{tabular}

Notes: $\mathrm{R}^{2}=0.767$; Adjusted $\mathrm{R}^{2}=0.728$; * significant at 0.05 level; ${ }^{* *}$ significant at 0.01 level; ${ }^{* * *}$ significant at 0.000 level. 


\begin{tabular}{|c|c|c|c|c|}
\hline \multicolumn{5}{|c|}{ MEANS AND STANDARD DEVIATIONS OF ONLINE CLOTHING REVIEW HELPFULNESS } \\
\hline Indicator & $\begin{array}{l}\text { Experiment } \\
\text { manipulation }\end{array}$ & $\begin{array}{l}\text { Online review helpfulness } \\
(\mathrm{N}=260) \text { Mean(SD) }\end{array}$ & F-ratio & Sig. \\
\hline \multirow{2}{*}{ Review valence } & Positive & $3.91(0.49)$ & \multirow{2}{*}{53.89} & \multirow{2}{*}{$0.000^{* \star \star}$} \\
\hline & Negative & $4.69(0.55)$ & & \\
\hline \multirow{2}{*}{ Review variance } & Consistent & $4.05(0.58)$ & \multirow{2}{*}{45.47} & \multirow{2}{*}{$0.000^{* * *}$} \\
\hline & Inconsistent & $4.62(0.62)$ & & \\
\hline \multirow{2}{*}{ Review concreteness } & Concrete & $3.83(0.55)$ & \multirow{2}{*}{63.86} & \multirow{2}{*}{$0.000^{* \star *}$} \\
\hline & Abstract & $4.68(0.57)$ & & \\
\hline
\end{tabular}

Notes: ${ }^{* * *}$ significant at 0.000 level.

H3 were supported. The two-way interaction of online clothing review concreteness and online clothing review valence $(F=42.653, p=0.001)$, and the twoway interaction of online clothing review valence and review variance $(F=12.275, p=0.006)$ were also significant. Table 2 shows a mean score difference for negative reviews (Mean $=4.69, \mathrm{SD}=0.55$ ) and positive reviews (Mean $=3.91, \mathrm{SD}=0.49$ ) was observed $(F=53.89)$, which means negative reviews had significantly higher perceived helpfulness than positive reviews. Therefore, $\mathrm{H} 2 \mathrm{a}$ was supported. A mean score difference for consistent reviews (Mean $=4.05$, $\mathrm{SD}=0.58$ ) and inconsistent reviews (Mean $=4.62$, $\mathrm{SD}=0.62)$ was observed $(F=45.47)$, which means inconsistent online clothing reviews had significantly higher perceived helpfulness than consistent online clothing reviews. Therefore, $\mathrm{H} 3 \mathrm{a}$ was supported. A mean score difference for concrete reviews (Mean $=3.83, \mathrm{SD}=0.55)$ and abstract reviews (Mean $=4.68$, $\mathrm{SD}=0.57)$ was observed $(F=63.86)$, which means online clothing reviews with abstract content had significantly higher perceived helpfulness than concrete ones. Thus, H1a was supported.

\section{CONCLUSION AND DISCUSSION}

\section{Conclusion}

Online clothing review has become one of the most influential information sources for purchase behaviour regarding apparel products. A growing stream of literature investigates the factors explaining the helpfulness of online reviews. Adding to previous research, our study aimed to understand the impact of online clothing review concreteness, online clothing review variance and online clothing review valence on individual's perceived review helpfulness. To achieve the research goals, an experimentally designed survey was conducted on real potential online clothing shoppers in China. Results indicate that online clothing review concreteness, online clothing review variance and online clothing review valence are significant factors affecting review helpfulness. This study's findings show that abstract review, negatively review and inconsistent review has a stronger effect on online clothing review helpfulness than a concrete review, positively review and consistent review. Additionally, given the nature of online reviews, consumers are exposed to different online cues at the same time.
Two-way interaction effect of online clothing review concreteness and online clothing review valence on the helpfulness of online clothing reviews was confirmed. Two-way interaction effect of online clothing review valence and review variance on the helpfulness of online clothing reviews was also confirmed. This outcome suggests that the effect of the online clothing review concreteness on the helpfulness of clothing online reviews is moderated by online clothing review valence; the effect of the online clothing review valence on the helpfulness of clothing online reviews is moderated by online clothing review variance.

\section{Implications}

This study contributes to the research on online reviews, has a number of theoretical and managerial contributions. To our knowledge, this research is the first to introduce and systematically examine the role of online clothing review concreteness, online clothing review variance and online clothing review valence in enhancing online clothing review helpfulness.

Our findings contribute to the decision-making literature in several ways. It enriches our understanding of attributes that affect online clothing review helpfulness. From a theoretical point of view, our results in the context of the clothing industry are new as no previous research has investigated the influence of content cues on clothing products in the predicting online review helpfulness process. A new product category not only enriches the sample variety but is also necessary to enable the generalization of suggested theories.

The variance, concreteness, and valence of the information provided in online reviews should be leveraged by marketing managers to improve the overall quality of the information hosted on their websites. Marketers can adopt the content criteria identified in this study as guidelines for review submissions. By utilizing more helpfully online reviews, clothing company are likely to be more effective in their online marketing campaigns; online clothing review writers are able to write more helpful or attractive reviews.

The empirical result of the current research, specifically the superiority of abstract reviews, can serve as new guidance for clothing firms' online review marketing strategies. According to the study, most potential consumers perceive the value of abstract reviews 
to be higher. Thus, it is assumed that abstract reviews that include experiential information are practically important in influencing consumers. Online clothing reviews with long, objective information may be found to be unattractive because they are unlikely to be considered actual buyers' comments due to the absence of sympathetic information.

Due to the helpfulness of negative online review, Clothing retailer must pay close attention to negative reviews and respond promptly by providing timely and sincere service recoveries. Thus, the clothing retailer should create standard procedures and protocols in responding to negative reviews to ensure that responses are personally tailored to address review contents.

\section{Limitations}

Despite the theoretical and practical implications, there are several limitations to this research. For example, this research survey was based on a hypothetical situation and, therefore, the intrinsic difficulty in controlling the exogenous factors affecting an experimental method could not be avoided. Despite the improved internal validity compared with that of the previous studies, this study's results were drawn from experiments and may be detached from a practical situation. Furthermore, the empirical findings are based on clothing products, which are different from common consumer goods. Since research suggests that product type may play an essential role in determining the perceived helpfulness of online reviews, replicating the study with other products or product types may reveal additional insight. Therefore, replication studies in different contexts are necessary to enable the generalizability of our findings and further explore potential differences among various product categories. Future researchers may identify other antecedents of online clothing review helpfulness, such as reviewer characteristics. Moreover, the study gets data from lab experiments, and the sample size is relatively small. Actual review data from online platforms would be helpful in strengthening the findings of the study.

\section{REFERENCES}

[1] Filieri, R., What makes online reviews helpful? A diagnosticity-adoption framework to explain informational and normative influences in e-WOM, In: Journal of Business Research, 2015, 68, 6, 1261-1270

[2] Rahman, M.S., Mannan, M., Consumer online purchase behavior of local fashion clothing brands: Information adoption, e-WOM, online brand familiarity and online brand experience, In: Journal of Fashion Marketing and Management, 2018, 22, 3, 404-419

[3] Fresneda, J.E., Gefen, D., A semantic measure of online review helpfulness and the importance of message entropy, In: Decision Support Systems, 2019, 125

[4] Haddara, M., Hsieh, J., Fagerstrom, A., Eriksson, N., Sigurdsson, V., Exploring customer online reviews for new product development: The case of identifying reinforcers in the cosmetic industry, In: Managerial and Decision Economics 2019

[5] Zhang, J., Liu, R.R., The more the better? Exploring the effects of reviewer social networks on online reviews, In: Journal of Marketing Management, 2019

[6] Shin, S., Chung, N., Xiang, Z., Koo, C., Assessing the Impact of Textual Content Concreteness on Helpfulness in Online Travel Reviews, In: Journal of Travel Research, 2019, 58, 4, 579-593

[7] Karimi, S., Wang, F., Online review helpfulness: Impact of reviewer profile image, In: Decision Support Systems, 2017, 96, 39-48

[8] Gang, R., Taeho, H., Examining the relationship between specific negative emotions and the perceived helpfulness of online reviews, In: Information Processing \& Management, 2019, 56, 4, 1425-1438

[9] Jia, Y., Liu, I.L.B., Do consumers always follow "useful" reviews? The interaction effect of review valence and review usefulness on consumers' purchase decisions, In: Journal of the Association for Information Science and Technology, 2018, 69, 11, 1304-1317

[10] Huang, L., Tan, C.H., Ke, W., Wei, K.K., Helpfulness of Online Review Content: The Moderating Effects of Temporal and Social Cues, In: Journal of the Association for Information Systems, 2018, 19, 6, 503-522

[11] Lo, A.S., Yao, S.S., What makes hotel online reviews credible?: An investigation of the roles of reviewer expertise, review rating consistency and review valence, In: International Journal of Contemporary Hospitality Management, 2019, 31, 1, 41-60

[12] Langan, R., Besharat, A., Varki, S., The effect of review valence and variance on product evaluations: An examination of intrinsic and extrinsic cues, In: International Journal of Research in Marketing, 2017, 34, 2, 414-429

[13] Cheung, M.Y., Luo, C., Sia, C.L., Chen, H., Credibility of Electronic Word-of-Mouth: Informational and Normative Determinants of On-line Consumer Recommendations, In: International Journal of Electronic Commerce, 2009, 13, 4, 9-38

Authors:

YIBING SHAO, XIAOFEN JI, LILIN CAI, SONIAAKTER

Zhejiang Sci-Tech University, College of Materials and Textiles, Zhejiang, China

\section{Corresponding author:}

XIAOFEN JI

e-mail: xiaofenji@zstu.edu.cn 